\title{
NEGOTIATING SERVICE LEARNING THROUGH COMMUNITY ENGAGEMENT: ADAPTIVE LEADERSHIP, KNOWLEDGE, DIALOGUE AND POWER
}

\author{
Julia Preece \\ University of KwaZulu-Natal \\ preecej@ukzn.ac.za
}

\section{ABSTRACT}

This article builds on two recent publications (Preece 2013; 2013a) concerning the application of asset-based community development and adaptive leadership theories when negotiating university service learning placements with community organisations in one South African province. The first publication introduced the concept of 'adaptive engagement'. The second analysed empirical findings from the first phase of an action research project that endeavoured to take a teamwork approach to service learning placements. This paper reports on the larger, second phase. Different student teams were each tasked with undertaking an activity that had been identified by an NGO as an area of development need. The paper discusses this approach filtering the above-mentioned theories through a Foucauldian lens for analysing power relationships, knowledge and ownership over decision-making. Findings highlight the multi-layered complexity of community engagement, communication and power relations, and the limiting nature of institutional governmentality in terms of student contributions to sustainable community outcomes and university recognition of communitybased knowledge. But the findings also demonstrate the potential for contributing to community change and knowledge sharing when an adaptive leadership approach of clarifying competing goals and values is used alongside respect for community assets of experiential, or subjugated, knowledge.

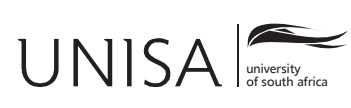

Education as Change www.educationaschange.co.za Volume 20 | Number 1 | 2016 pp. 104-125

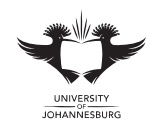

DOI: http://dx.doi.org/10.17159/1947-9417/2016/562 Print ISSN 1682-3206 | Online 1947-9417 (C) 2016 The Author 
Keywords: adaptive leadership, asset-based community development, community engagement, service learning, power

\section{INTRODUCTION}

Community engagement and service learning are now popular concepts for universities in South Africa and the wider world. Global and international networks exist to encourage debate and networking. A prime example of the interconnectedness of this movement is the 2014 Talloires Network Leaders Conference in Cape Town, South Africa, which is co-sponsored by the South African Higher Education Community Engagement Forum (SAHECEF) and promoted by significant other organisations such as the Global Universities for Innovation (GUNI). Similar national networks (such as Community Engagement Australia) and networks of networks (such as the PASCAL International Observatory) exist throughout the world. A journal focusing on community engagement issues is currently under consideration in South Africa and other dedicated journals exist, such as the Journal of Higher Education Outreach and Engagement in the United States.

Community engagement (CE) research has now become an academic field in its own right. Several models for CE have been promoted, ranging from the silo, intersecting and infusion models as articulated by the Council for Higher Education (CHE 2006), to the entrepreneurial, networked, traditional and consultancies matrix as outlined by Kruss (2012). The different forms of CE have been analysed by O'Brien (2012) to reveal that they range from philanthropic models to those that actively promote change and community empowerment. The scope of CE partnerships is wide. At a macro level, universities act as network players in broad lifelong learning agendas for learning regions or cities (UIL 2013). Universities also develop industry and government knowledge production partnerships as entrepreneurial activities (Laredo 2007). At the more traditional, micro level of small-scale activities, universities link with local community residents to contribute to a specific area of need (Preece 2013a; O’Brien 2012).

Service learning (SL) is one form of community engagement (Van Schalkwyck and Erasmus 2011), although SL research has tended to focus more on its pedagogical and curriculum purpose for the participating students (for example, Bender 2008; Hlengwa 2010; Petersen \& Henning 2010). This paper concentrates on the community-student relationship.

A number of writers have questioned both the feasibility and quality of short-term SL projects in relation to the longer-term goals of CE (for example, Mahlomaholo \& Matobako 2006; Osman \& Castle 2006). A further concern is that the community voice is less often heard within research analysis (Alperstein 2007; Nduna 2007), and the community-university power relationship is insufficiently analysed in relation to CE (Camacho 2004; Nduna 2006; Osman \& Attwood 2007; Parker, Myers, Higgins, 
Oddson, Price \& Gould 2009). More recently Preece (2013) has presented the notion of 'adaptive engagement', which draws on community development theory and organisation management theory as a conceptual framework to facilitate analysis of power dynamics between students and their communities.

This article discusses recent literature that reflects power in the community engagement relationship. It revisits Preece's (2013) theoretical framework that uses asset-based community development theory (Swanepoel \& De Beer 2011; Ferreira \& Ebersöhn 2012) alongside Heifetz's (1994) concept of adaptive leadership. It then outlines the methodology for the study followed by analysis and discussion of the findings and recommendations for future practice.

\section{Power and dialogical relationships in community engagement}

This paper adopts a Foucauldian notion of power as a relationship in which individuals may collude or resist, but which operates through discourses or common sense rationales as a means of bringing power relations into being. Other writers have also drawn on Foucault, particularly in relation to service learning. Osman \& Attwood (2007), for instance, analyse a service learning project in South Africa in order to critically assess the fluid nature of power relations between the different community and university participants. Lounsbury and Pollack (2001) draw on Foucault to assess the shifting discourses of service learning in an American university. Camacho (2004) does not explicitly refer to Foucault in his discussion of power and privilege in Tijuana, but does adopt a similar critical theory perspective to assess 'sites of power' (2004:13) in terms of how students respond to power relations in service learning contexts.

According to Foucault (1980), power and knowledge are interdependent. Although power is everywhere, dominant forms of knowledge are discursively protected through a complex system of techniques and curriculum structures in educational institutions. Subjugated knowledges are localised knowledges that are often ignored by institutions. In this study, subjugated knowledges refer to knowledge that is vested in communities. Power and knowledge are associated with authority to know, and circulated through agents of power (university academics, students, community members) (Preece 1999; Osman \& Attwood 2007). An act to disrupt the flow and balance of power can be initiated through enhanced awareness by the participants. Dialogue is the interactive process of renegotiating that relationship requiring 'multiple layers of involvement' (Caister, Green \& Worth 2011:35). The above writers have illustrated a concern for a more consultative form of leadership in the community engagement process, recognising that power is a relationship that needs to be de-stabilised in order to facilitate shared ownership of change.

In an effort to address this power challenge, Stephenson borrowed Heifetz's(1994) notion of adaptive leadership (AL) as a university strategy for enabling communities 
to take responsibility for decision-making, thereby steering communities away from developing a dependency relationship with the university. Heifetz's (1994) concept of AL does recognize power differentials within a leadership relationship, but he is concerned with using the power relationship as a resource to mobilise dialogue and respect for diversity of views, with the ultimate goal that people will take responsibility for decision-making through a process of facilitated clarification and dialogue. $\mathrm{He}$ thus shifts the notion of leadership from one of authority to know to that of a practice that can be used where there is a need to focus on change. AL has been cited as a progressive form of leadership that is gaining increasing credence as being suitable for responding to complex challenges when there is a need for more collaborative approaches to solving problems (Hartley \& Bennington 2011). Heifetz (1994:99) argues that community problems or challenges are often complex - defined as either type II ('defined problem, no clear-cut solution') or type III ('ill defined problem') situations. Type I problem is understood as one whereby a mechanical or surgical 'quick fix' can produce an isolated solution. But imposed technical solutions do not necessarily address the needs of complex community contexts. Type II or type III problems require a more organic and evolutionary approach to change. Addressing such problems entails ongoing dialogue, compromises and clarification of competing goals and values among the participating actors. In a later work (Heifetz, Linsky \& Grashow 2009), the authors explain that the adaptive process focuses on building on past ideas in order to examine what is no longer useful, with a view to encouraging shared awareness and interest in adapting and responding to new ideas.

The notion of AL has been used by the medical profession to facilitate new approaches to home-based health care reform (Eubank, Geffken, Orzano \& Ricci 2012). It has also been a point of reference for exploring new ways of engaging the public in environmental sustainability issues (Burke 2007). The concept has been likened by Grint (2005:1473) to 'Rittell and Webber's (1973) typology of Tame and Wicked Problems'. 'Tame' problems are, like type I problems, resolvable through 'unilinear acts', which have clear solutions. 'Wicked' problems are complex with no easy solutions and reflect Heifetz's type II or type III descriptions. Other concepts, such as the 'collective impact' approach (Kania and Kramer 2011) have also been compared with AL to describe the changing nature of a leadership style that recognises the multi-dimensional nature of community challenges, whereby shared ownership of solutions is advocated.

In spite of these varied sources of support for AL, the concept is not without its critics. Baylor (2011:30), for instance, suggests that the approach is still embedded in a corporate business model that favours 'charismatic personas, masculinity and Western culture'. Moreover, the skills required to manage potential resistances to change are seen as oversimplified. From a Foucauldian perspective, this system of leadership reflects a particular technique of 'governmentality' (Marshall 1990; Moss 1998), whereby under a discourse of care, justified through practices that legitimate 
acts of consultation, the institution ensures political obedience by participants who are acted upon as consultees.

Nevertheless, Stephenson (2011) suggested that AL values can be applied to a CE process whereby universities act as facilitators to help communities interpret and define solutions to their own problems.

This requirement poses challenges to university community service learning, which draws on students who are often young and inexperienced in the application of their theoretical knowledge to real work contexts and where engagement is timelimited. Service learning (SL) itself is a particular university technique and apparatus of power-knowledge that is embedded in a discourse of community engagement, which operates as an instrument of community care. It is commonly defined as an academic programme whereby students undertake a time-bound community placement and are assessed on the learning they derive from the experience. The experience is aimed at increasing a sense of social responsibility among students and providing them with an opportunity to put theory into practice. However, it is also expected that the SL is a negotiated activity that meets agreed upon goals with the community agency (Stellenbosch University 2009; Bringle \& Hatcher 1995).

A number of people have critiqued the extent to which SL is either a dialogic or a mutual relationship between the participating stakeholders (see, for example, Mitchell \& Rautenbach 2005). Mahlomaholo \& Matobako (2006) identify at least three potential levels of community relations in SL. These are the levels of charity 'in the community', project activities in or of the community, and finally a genuinely collaborative activity 'of the community' (2006:204). This third activity has emancipatory potential whereby university engagement activities may focus on change within communities. Mahlomaholo and Matobako claim that the government enshrined policy approach to service learning (DoE 1997; DoHET 2013) is too academic and has lost its connection to the communities themselves. More recently, O'Brien (2012), in a study of 36 SL experiences, produced a framework of four SL engagement 'Discourses', which were defined as scholarly, benevolent, democratic and professional (2012:208), covering distinctions of purely academic interest, technical inputs, and more collaborative arrangements. O'Brien (2012), among other writers, stresses the challenge of negotiating differential power relations in a situation where university knowledge has greater legitimacy over locally constituted knowledge. From a Foucauldian perspective, the university is a site for the exercise of power that generates particular forms of knowledge through disciplines legitimized in the name of expertise. O'Brien emphasises that engagement relationships that build on dialogue - as opposed to merely consultation - are more likely to contribute to social action or change where the emphasis of the engagement relationship shifts to 'understanding the other's life space rather than necessarily converting that space to mirror one's own' (O'Brien 2012:203). In such contexts she emphasises that the pedagogical goal of the SL activity is to raise awareness among participating students 
of these differential power relations and the need to foster 'interdependence' rather than dependence. This aspiration raises power-knowledge tensions that the students have to navigate in their community relations.

This tension is also historically constituted through notions of governmentality (Miller and Rose 1993) whereby university procedures, techniques and knowledges have already defined, labeled and characterised communities as marginalised, poor, disempowered and in need of care. This has a particular resonance in postapartheid South Africa whereby universities' responsibilities to their communities were enshrined in government reform policy for higher education. Thus the act of SL as a benign act upon communities is legitimated. The theories of community development and AL reinforce these discourses. Nevertheless, the AL theory (essentially recognising the leadership role that universities inevitably play in the service learning initiatives) is offered as a contribution to community development theory that focuses on participatory reflection and building on community assets as essential resources for the community empowerment process. The combination of AL and asset-based community development theory was captured by Preece (2013) as 'adaptive engagement'. It is a possible discursive resource that reverses the institutional domination of knowledge and provides space for subjugated knowledges to be recognised.

The concept of asset-based development, as articulated by Swanepoel and De Beer (2011) and Ferreira \& Ebersöhn (2012), still recognises the role of intervention in communities as a process of planning 'with the people' (De Beer \& Swanepoel 1998:7), but it takes as its starting point the position that all communities have existing resources of resilience, coping skills and knowledge that need to be built into any development process: 'The goal in community development is to work with and build on existing assets in order to construct a resource-led foundation for development which is controlled by the community rather than by external agents' (Preece 2013a:990) - in other words, recognising power and knowledge 'from below'. The dialogic process of engagement for community development is an ongoing one of collaboration (Schmied, Mills, Kruske, Kemp, Fowler \& Homer 2010), where competing aims are often re-visited and where communication takes time and effort. However, the multi-layered nature of engagement often poses communication challenges and tensions of power relations whereby one layer of the community may have been consulted, but that consultation does not necessarily filter down to other layers (Osman \& Attwood 2007; Preece 2013a).

The study that this paper refers to was conducted in 2013 at the University of KwaZulu-Natal. It asked local NGOs to identify small-scale projects that could be undertaken by students with the NGOs' constituent community members and that would contribute to the development goals of the participating organisations. Efforts were made to ensure students and different participating members (for example, the NGO leaders and their community-based workers) had an opportunity to consult with one another prior to project commencement. 
The concept of 'community' - a contested term that this paper does not have space to expand on (see Hall 2010, for example) - was normally defined for the purpose of this study as a non-governmental organisation (NGO) or communitybased organization. The reason for this was because the student interventions were necessarily time bound and it was important that dialogue could take place with established structures in order to avoid some of the sustainability issues of short-term engagement that have been articulated by writers such as Mahlomaholo and Matobako (2006). However, in two of the case studies, grass-roots community members - as employees or client groups of the NGO - were also involved. Reflexivity (Osman and Attwood 2007) through action research was the process that examined power relations and the effectiveness of the dialogic processes.

\section{METHODOLOGY}

The study took a multiple, comparative case study approach and was a partnership between the Faculty of Education at the University of the Free State Qwa Qwa campus and two schools (Education and Politics) in the College of Humanities at the University of KwaZulu-Natal (UKZN) Pietermaritzburg campus. It formed the second cycle of an action research study that was initiated in 2011 with four case studies at KwaZulu-Natal. That cycle informed the larger study through findings that highlighted the need for greater clarity of competing goals and values at project inception (Preece 2013a).

Both action research cycles drew on the UKZN's CE/SL strategy to support the notion of 'responsible community engagement' (UKZN goal 2). It is in line with the UKZN College of Humanities Community Engagement Strategic Plan 2012-2016, which aims to examine the potential for integration of $\mathrm{CE}$ work across disciplines, through education and training of UKZN students and solving community issues as part of an ongoing engagement relationship.

The research questions pertinent to this paper were:

- To what extent does a theoretical framework of adaptive leadership and assetbased development illuminate the CE process?

- How do students and communities negotiate power relations and co-creation/ sharing of knowledge?

Action research is traditionally 'concerned with improvements within the context of a study [i.e., solving a given problem]' (Tomal 2005:5). It is a common feature of educational research since it includes research intervention for implementation, rather than simply a data collection process. The action research inquiry process is cyclical. In addition to collecting and analysing data, it also includes communicating outcomes, capturing stakeholder views and taking action in response to those views in order to improve or resolve the issue under investigation (Stringer 2004). 
Since the project included the development, and implementation of, action plans within each participating institution in the pursuit of practical solutions with potential for repeating this cycle, such an interventionist research approach was deemed the most suitable for this study. The following definition of action research, cited in Stringer (2004:4), was used:

A participatory, democratic process concerned with developing practical knowing in the pursuit of worthwhile human purposes .... It seeks to bring together action and reflection, theory and practice, in participation with others, in the pursuit of practical solutions to issues of pressing concern to people.

To reflect that process, each cycle of the action research applied four phases: initial consultative meetings with community-based stakeholders, a planning process involving negotiations between community and university stakeholders, an implementation phase that was evaluated, followed by a fourth phase of stakeholder consultation, revised action planning and policy recommendations.

This second cycle at UKZN involved eight case studies, across five academic courses, in which 38 students from a variety of Humanities disciplines participated. However, for reasons of space, only three case studies will be discussed here. They were selected because in these projects students were specifically asked by the NGOs to facilitate change as one of their goals. This concept was presented differentially at grass-roots level by each NGO, but was usually articulated as an opportunity to 'learn from each other'. They therefore provided an opportunity to explore the dynamics of power relations between students and community members.

Rule and John (2011:4) define a case study as 'a systematic and in-depth investigation of a particular instance in its context in order to generate knowledge'. The case studies in this instance represent units of study, products of investigation and also a methodological process (ibid.:5). Their purpose was primarily explanatory (Yin 2003) in that the research project was attempting to explain what was happening in each context. But there was also a comparative element to the case studies to strengthen understanding of the findings in relation to the research questions and counter criticisms regarding lack of generalisability for case study investigations.

\section{THE CASE STUDIES}

The case studies were small-scale activities, each involving a minimum of two students from two or more disciplines with a community organisation or service provider. The service learning commitment was approximately 30 hours over a time frame of approximately three months, though these 30 hours sometimes included desk-based research or preparation time in addition to practical participation in the field. The community contacts operated on several levels and with varying degrees of complexity. The following table summarises the projects and participants. 
Table 1: Summary of SL projects undertaken between August and November 2013

\begin{tabular}{|c|c|c|c|}
\hline Project & Students & $\begin{array}{l}\text { Community } \\
\text { members } \\
\text { interviewed }\end{array}$ & Task \\
\hline $\begin{array}{l}\text { CS1 - early child } \\
\text { development } \\
\text { project in a peri- } \\
\text { urban location }\end{array}$ & $\begin{array}{l}\text { Year } 3 \text { Education } \\
\text { and development } \\
\text { SL students (S1 } \\
\text { and S2) }\end{array}$ & $\begin{array}{l}\text { Community } \\
\text { coordinator CC } \\
\text { Community } \\
\text { facilitator (CF) } \\
\text { Parents (P1-P2) }\end{array}$ & $\begin{array}{l}\text { Assist in conducting and } \\
\text { improving non-formal crèche } \\
\text { activities in garden of a } \\
\text { township house }\end{array}$ \\
\hline $\begin{array}{l}\text { CS2 - publicity } \\
\text { material for } \\
\text { disability advocacy } \\
\text { NGO in the city }\end{array}$ & $\begin{array}{l}\text { Year } 4 \text { Media } \\
\text { Studies Honours } \\
\text { students (S1- } \\
\text { S12) }\end{array}$ & $\begin{array}{l}\text { NGO staff } \\
\text { (NGO1-2) }\end{array}$ & $\begin{array}{l}\text { Improve the NGO's corporate } \\
\text { image with enhanced } \\
\text { publicity material }\end{array}$ \\
\hline $\begin{array}{l}\text { CS3 - national } \\
\text { reading club } \\
\text { campaign NGO in } \\
\text { a rural location }\end{array}$ & $\begin{array}{l}\text { Education and } \\
\text { Development } \\
\text { students (S1 } \\
\text { \& 2); Master's } \\
\text { students studying } \\
\text { M \& E (S3 \& S4) }\end{array}$ & $\begin{array}{l}\text { Reading site } \\
\text { manager (RCM) } \\
\text { Reading club } \\
\text { facilitators (RCF } \\
1-4)\end{array}$ & $\begin{array}{l}\text { Implement new M \& E tools } \\
\text { requested by NGO and } \\
\text { feedback findings }\end{array}$ \\
\hline
\end{tabular}

Case study one (CS1), an early child development project, managed by a community college, trains unemployed grass-roots community members of a peri-urban township to run non-formal crèche activities for children whose parents are either too poor or situated too far from the township's pre-school. An initial meeting between two students, the college trainer, the local crèche coordinator and community facilitators established who would work with the students, the kind of activities that the crèche provided and the days on which the students would participate as co-facilitators. Parents were not involved in these discussions though two attended the activities and were subsequently interviewed.

The second case study (CS2) was a disability advocacy non-governmental organisation (NGO) with two full-time staff members and a part-time assistant. The NGO presented its overall objectives and a specific request for assistance with improving its corporate image through publicity material to a class of twelve Media Studies Honours students. The students worked in two teams to devise publicity brochures for corporate communication and general publicity about the NGO's activities.

Case study three (CS3) was a multi-layered NGO initiative to facilitate a national reading campaign for young children. The NGO asked students to assist with monitoring and evaluation of the reading clubs. Four students (two from Education, two from a Master's level monitoring and evaluation research module) received initial training in the use of the monitoring and evaluation tools with the national 
coordinator via Skype; one student then liaised with the local coordinating NGO and the reading clubs site manager to identify times when the students could visit and monitor four of the reading clubs (run by unemployed grass-roots community members). The grass-roots facilitators in this case did not meet the students prior to the project but were informed by the regional coordinator of the students' involvement. Thus, the multi-layered nature of this project meant that not all participants shared in the initial negotiations, though all were interviewed as part of the research.

At the end of the field work phase, participating student teams, community members and NGO implementers for each case study were interviewed separately with questions that sought to examine levels of satisfaction with the engagement experience as well as efforts to understand experiences of working together, communicating and learning from one another.

In order to ensure trustworthiness of data (Savin-Baden \& Howell Major 2013), a number of strategies were used. First, triangulation included collecting data from a range of participants (academic, NGO, student and community members); data collection also included several site visits and field note observations from research assistants. Second, an audit trail of data was assured through digital recordings of interviews, which were then transcribed verbatim (though the research assistants translated isiZulu recordings direct into English in most cases). Third, data and findings were subjected to 'member checking' whereby all participants were invited to respond to the initial analysis phase. The data were subjected to an open and axial coding process as advocated by Glaser and Strauss and cited in Savin-Baden \& Howell Major (2013). This entailed reading and re-reading the data, through an inductive process, whereby key sentences were identified and compared across the different interviews as patterns, which were then coded into initial themes. This formed the open coding process. The axial coding process required the data to be subjected to a second layer of analysis whereby the initial themes were categorised and converted into umbrella themes that could be interpreted critically in relation to the theoretical framework. This was obtained through a process of 'constant comparison' in order to 'compare codes and passages to those already coded' (Savin-Baden \& Howell Major 2013:437). The themes that are discussed here relate to the dialogic process of knowledge sharing and co-creation, addressing power relations and the related issues of working together and communication. These themes are also discussed in relation to the theoretical concepts for AL and asset-based development.

\section{Findings}

The following themes are selected from the overall findings and the interview quotations illustrate those themes. 


\section{Knowledge - sharing and co-creation}

Knowledge, in Foucauldian terms, is defined by the 'possibilities of use and appropriation offered by the discourse' (Foucault 1972:183). It is therefore an instrument of power and held in place by techniques and practices that claim its legitimacy. The academy is accorded authority to know through its internal techniques and procedures that maximise its domination over knowledge through disciplines. The students in the early child development project quickly realised, however, that the knowledge they possessed was only a partial resource that needed to build on existing community assets (subjugated knowledges):

They had so much knowledge already. So our role was just to add on that factor of knowledge .... The experts are the people themselves ... as compared to as much as I might sit here at UKZN and learn about early childhood development and community work ... whatever I have learned at [university] for example, it is not the same. The real experts of that area, of that programme are the people that are going through that experience so ... whatever I have learned that is on paper ... we could say we are the real experts whereas we get there and introduce something that we think they need, [but] they might probably think that "no this is not for us" (CS1, S1 \& S2).

Thus, their experience of working with people labelled as deprived exposed them to contradictions that disrupted their own regime of truth that they were the ones who had been vested with expertise through their immersion in the governmentality of the university. The community members, however, in two of the projects, described knowledge more as a resource to be shared, where ownership over knowledge and authority to know appeared more fluid:

If they have an opinion they would share and I would also do the same when I had an opinion about the children ... see they are also educated - they came with the shapes and the robots ... [but] this one day they finished with shapes and proposed to teach them about robots. We told them no, they shouldn't - these children are still young, they shouldn't learn everything at once in a day ... we also learned that whenever you give a child paper they should write their name and surname at the top of the page (CS 1, CF).

They (reading club facilitators) also picked up a few lessons from the students ... working with other people is nice, sharing ideas, you here interacting with us, asking us questions. We love things like this, to be able to learn how we can improve our work (CS3, RCF4) .... What I learned was that you should be able to sit down with a person and listen to them, try to understand everything they say (CS 3, RCF3).

Such forms of knowledge are often referred to as mode 2 knowledge or 'socially robust knowledge' whose locus is in practice-based contexts (Gibbons 2006:28). Most of the knowledge being constructed or shared in the engagement activities could be associated with mode 2 knowledge. Within their own domains, community members saw their subjugated knowledges from a different perspective. While the academy had inscribed its own mode 1 knowledge as superior, within the community- 
based discourses other rationales came into being that reflected Gibbons's mode 2 knowledge. In case study one this was most evident as the community facilitators resisted the students' efforts to appropriate their own sites of knowledge, thus resisting the power imbalances. But there was also mutual recognition of the potential of fresh ideas coming from mixed sources. From the point of view of the NGO in case study two for instance:

It has been interesting to have people outside the disability field looking at what they think should be in the brochure that we might not think of would be so applicable so it's quite nice getting the outsider's view .... I also gave them quite a lot of information to be included in the different brochures (CS 2, NGO1).

Similarly the students recognised that 'knowledge' extended beyond the formalised curriculum:

We learnt about the plight of the NGO and their reaching out to a different sector that we were not really knowledgeable of before ... we were also able to learn about things that weren't really part of our curriculum ... we were able to learn about disabilities and things that surround issues of disability ... and by really understanding and feeling what those people are going through we were able to communicate their message better (CS 2, S3 \& S4).

These observations occasionally resulted in insights that deconstructed the discontinuity between mode 1 (academic and discipline specific) and 'socially robust' knowledge:

I find that we often go into situations with a very singular thinking and we think only from our own perspectives and the information that we have in our head and everything that we have been taught, but when you work with other people who are specialist in their fields as well you see something from a different perspective and it teaches you to respect their knowledge and respect what they have put in years and years of work to build up and develop (CS 2, S5).

Power, however, also manifests itself in relationships, especially in contexts where the normative status of individuals is inscribed through institutional labels such as a university. This power relationship played out in different ways and is identified here as different discursive forms of power.

\section{Addressing power dynamics}

Power itself is a dynamic process that puts into circulation certain forms of knowledge colonised by apparatuses of power such as the university. One student represented this site of knowledge but also saw herself as a subject upon which the university and community both acted. She saw herself both as a subject who is acted upon by, and also a vehicle of, the university's power dynamic: 
As a student, when I'm here [in the university] I see myself as a nobody but then when you get to places with people [in community settings] being a student is a big thing (CS1, S1).

These different power dynamics had to be managed. For instance, even though the early child development students felt they could contribute added value to their placement (power knowledge):

Since we are students ... I think we have like more, fresher ideas of teaching children compared to the facilitators there; even though it was threatening but then we had fresher ideas. We had new ways of implementing the teaching ... we tried to have more fun ways of learning for the kids (CS1, S2);

They soon became aware that the introduction of those ideas required a conscious awareness of community sensitivities (power resistance):

What I learned was the facilitators they take this job very seriously, it is kinda like it's their baby and if someone else from the outside tries to intrude somewhere ... you are attacking them personally so ... if you want to intervene ... do it in a way that ... does not seem as if you are attacking them, in a way that we are here to learn $(\mathrm{CS} 1, \mathrm{~S} 1)$.

Sometimes that meant holding back in terms of the knowledge they felt they could contribute:

This was a learning curve that this [project] is their baby so we were afraid to raise some points because maybe she would take it as though you are undermining her position. That was also a challenge for us (CS1, S2).

The students' concerns not to exploit or abuse the engagement relationship applied also in case study two when working with their NGO leaders, indicating several flows of power that circulate between the university students as agents of disciplinary knowledge that has discursive authority and the client relationship that requires a more consultative power dynamic:

I think it is also important to understand that when you work with a non-profit organization that a ... consultative partnership is very different so you're working on the line of participation more and not overwhelming the other party with all your knowledge and saying "we can do this we can do that" we learned to pace all our knowledge and adapt to the capacity of the organisation that we were working with ... so it taught us to hold back and only give what they can use (CS2, S5).

However, the students in this case study did not really reflect on the contingent nature of their discipline specific (mode 1) knowledge in terms of whether that knowledge was 'socially robust' enough to be used by the NGO. The university's power status could, nevertheless, be used to good advantage as a motivator and a legitimating form of recognition of community-based work that is done by people with little formal education. The reading club facilitators emphasised this point: 
They [the students] made me see the importance of having people coming to evaluate your work, see how you are doing, point out your mistakes and your strengths (CS3, RCF1);

I can say we have benefitted a lot because the presence of someone outside the programme especially the university makes every worker be at their best ... the reading clubs that have been visited have become more alert and motivated compared to those that the students have not visited ... also ... the attendance of the clubs have increased because they know students from the varsity will arrive ... even the children have changed (CS3, RCM);

The early child development workers echoed similar sentiments:

We were very happy to be with you [students] and the children also saw - and I also saw that I am also important ... the children and parents saw that this is a legitimate thing .... Your presence helped because some parents thought this was just a game. Some even refused to allow their children to come ... now they saw that this thing of teaching from home is serious ... because of the students that came and brought some of their things as well and they saw. The children kept their stars as well ... they made a star for a child that did well ... we wish that you people could come back again because your presence has been noted by the parents (CS1, CF).

The community-based workers felt they were thus given greater status by their fellow community members because the university appeared to be showing interest in their work. In other words, the differential power relationship was taken as given but was appropriated by the grass-roots community members in a form of reverse discourse. But, within these relationships, it was important that the students showed respect and did not exploit this differential status:

When they [the students] arrived here they showed us love. They didn't have that attitude of treating us like strangers ... they showed us love and we united (CS3, RCF4).

Power in terms of status, therefore, when managed sensitively could be a positive feature of the engagement relationship. But although both parties reflected on these positive experiences, the SL activities in themselves did not disrupt the perception of power imbalances. It will be seen later, however, that there were occasions when community members did reverse this relationship.

Other power dynamics could manifest themselves more subtly, particularly with day to day interactions. The projects were designed to encourage students to plan and work together in teams. But working together also meant working with the community organisation members. The different projects made different demands regarding the extent to which students were required to work with, rather than for their host organisation.

\section{Challenges of working together}

The overall engagement goal, as articulated by the NGOs as mediators of the power relationship between university and the grass-roots community, was not necessarily 
to promote change in any organisational sense, but it was to motivate community members to take responsibility for decision-making and to provide added value to existing activities. There were occasions when the power relationship seemed to 'hang' between the participants.

For example, students in the early child development project cited one occasion where they were in a dilemma about how to work in harmony with their community partners, particularly on an individual basis. They were expected to contribute to an existing morning activity in the township, which was led by the community facilitator, and bring in resources that could be used during the activity sessions:

We didn't know how to do certain things with her [the community based child development facilitator], how do we engage with her in doing something because ... we took the plastics to her and said here are the plastics what should we do? ... and she was like "eish I don't know as well" (CS1, S1).

But they learned to find ways of mingling their ideas with the facilitator's existing ways of working, thus reflecting the objective of working with and building on existing assets, mobilising possibilities for dialogue:

When we arrive B would have started already ... our duty was to intervene ... with our creative ideas ... it's not that we used to change their whole plan ... just get in between what she is teaching ... she used to arrange her day her own way in most things but we would intervene here and there (CS1, S2).

It was apparent from the community members' perspective that respect for diversity of views and dialogue did take place, which allowed a level of power 'from below' whereby the community members became the subjects rather than objects of power:

We had different ideas and worked in a good partnership ... we used to discuss things; agree that they can take over now. They would tell the story they prepared and I would also tell some of their stories that they've told (CS1, CF);

They [students] just joined in. Sometimes we gave them a day from the beginning to start everything since they have seen, then let it be their day to do everything. They did it well, I must say ... I learned that if you are teaching each other we have to listen to each other and accept each other ... the main thing is to work together equally and in harmony ... we worked well together, it was nice (CS1, CC).

In one instance, the interview process itself stimulated new thoughts about working together. The early child development NGO had been trying to encourage parents to get involved in their children's learning activities. Two parents had not been party to the initial consultations but were nevertheless interviewed since they attended the crèche sessions. The university interview stimulated some parental reflection on the role they could play: 
No I haven't played any role [in the crèche] ... but now that you have asked me this you have motivated me to start taking part (CS1, P1).

It must be acknowledged, however, that the grass-roots community members were also in a power relationship with the student interviewer and some communication and participation issues for them could have been glossed over in an effort to please the interviewer. It was evident, for instance, that at NGO level a different power dynamic took place. The NGO was a self-constituted institution with its own governmentality and self-regulated role as a provider of services. Here the community voice was stronger so that the disability advocacy NGO was more willing to critique the working relationship between students and their organisation. When one group of Media Studies students complained that they did not get prompt replies to their questions while preparing the organisation's publicity brochure, the NGO defended their position by drawing on experiential knowledge that they felt the students did not have:

The students [have] got to .... realize for example we are not always in the office and that's a real experience of working in a company or an organization in that you cannot always get hold of the people you want when you want and you have to adjust and not do things at the last minute (CS2, NGO1).

This latter point raises further challenges about the limitations of SL as a CE strategy that aims for mutual benefits for both community and university. The university's discursive machine and its apparatus of governmentality was a hindrance for community relations. The students who needed to work to an examination deadline impeded the natural flow of the organisation itself and this experience highlights the fine line between academic and community priorities that cannot always be anticipated in the initial negotiating process.

Of course, working together requires communication at all stages of a collaborative relationship. And communication would not simply be a practical, logistical arrangement. Its success also depended on how one communicated. In two case studies, after the initial meeting between the NGO lead contact and university staff member, communication was primarily between the students and the community participants. Students had to sometimes feel their way through this process and there were indications that ongoing power differentials occasionally hindered understandings at the grass-roots and among students of what was required.

\section{Communication challenges}

One issue in community engagement relations is the multiple layers of communication. That is, it was not sufficient for the students to simply communicate among themselves: 
What we learned ... if we have ideas that we want to implement ... inform her that okay, we are thinking of this, to do this, is it alright? So that the other person is in the loop ... by the time we arrive she knows already that this is what's going to happen (CS1, S1 \& S2).

But in instances where there are several layers of contacts and multiple agents of power, all with their own apparatus of governmentality, it was not always easy to keep communication channels constantly open. The students whose task was to monitor and evaluate the reading clubs submitted their findings directly to the national coordinator. The reading club facilitators, at the end of the communication chain, felt that the monitoring and evaluation exercise required an additional feedback loop between the students and themselves:

It would be nice if you also expressed your views and suggestions where you see that no this is a mistake ... share with us your opinion because we are not hundred percent sure about how you viewed our work and we would like feedback on the work we do (CS3, RCF2).

\section{DISCUSSION}

An exploration of the power dynamics in these case studies suggests that within a short space of time, it is possible to stimulate new understandings among students about the nature of knowledge and how mode 1 knowledge has its limitations when applied in the real world. But the time-limited nature of such small-scale projects prevents deeper understandings of how subjugated knowledges can be integrated into the academy itself. Although these three projects were generally regarded as 'successful' in that student tasks were completed to the satisfaction of the participating institutions, communication issues that were unresolved indicated that, no matter how much competing goals and values appear to have been discussed at the project initiation stage, such goals and values can shift during project duration. Similarly, the extent to which people feel able to articulate legitimate concerns and make new decisions is an important power dynamic that needs to be recognised by the agency, which has been discursively inscribed as having the most authority to know. Furthermore, the nature of SL as a discourse that is embedded in the governmentality of university procedures and structures that define the university curriculum has implications for how usefully students can engage with their communities. In SL the focus is on helping students learn. In CE the focus is on responding to community expressed needs.

The AL philosophy of helping participants clarify competing goals and values provided a lens for examining how and when this happened. It also revealed there are several layers of communicating and working together that evolve during the relationship. It is, as Heifetz (1994) argues, necessary to be sensitive to context. The goal of AL is to enable individuals or groups to take responsibility for their own decisions and it was apparent that the students in these projects respected this 
process. The interviews illustrated the critical reflection that students undertook to maintain a working relationship, but the extent to which they allowed themselves to be objects rather than subjects of power varied.

The asset-based development theory provided a framework for exploring the extent to which community assets (subjugated knowledge in terms of skills, attitudes, knowledge and resources) were mobilised and expanded. Some of the projects lent themselves more readily than others to this purpose. The monitoring and evaluation project, for instance, by its very nature, was not designed to be a collaborative venture with the community reading club facilitators. It was responding to the middle level of the multi-agency chain of command. Similarly, the media studies students were completing a task that utilised the NGO's knowledge and experience, but essentially they were constructing a technical resource that had been requested by the NGO. The child development project, albeit on a small scale, did enable students and community participants to see how local knowledge could work with university knowledge in order to contribute to change (Ferreira \& Ebersöhn 2012).

The discursive goal of AL combined with asset-based community development is to reduce dependency on external mobilisers for change. By encouraging communities to identify their own needs and levels of technical expertise required to address those needs, ownership of the development process remained in the hands of those communities, so that the projects worked 'within society's own frame of reference' (Heifetz 1994:25). But the multi-layeredness of power dynamics in some $\mathrm{CE}$ projects revealed there may be several frames of reference to work with. The added value that Ferreira and Ebersöhn contribute to this goal of reducing dependency is that communities already have resources within their own communities that need to be harnessed. The early child development project was perhaps the best example of students and community members working together in dialogue to achieve that purpose. But it required constant vigilance regarding power dynamics that were vested in status, ownership over knowledge and communication that was sensitive to context.

\section{CONCLUDING REMARKS}

This article has discussed some practical and philosophical realities of university community engagement that employs service learning students to respond to community-expressed needs. It only discussed three out of a total of eight case studies, but in doing so highlighted some of the complexities of working with multi-layered community contexts. The combined theories of AL and assetbased community development, filtered through the Foucauldian lens of power/ knowledge, explored power dynamics, knowledge construction, decision-making and communication challenges that all serve to deconstruct the ideological notion of community engagement. The case studies revealed that reflective practice can 
produce tangible outcomes on a small scale for all participants. Recommendations for future CE practice that involves SL include the need to keep projects local and small and establish clear parameters at the outset regarding identification of participating members. University curriculum and timetable constraints need to be factored into all negotiations and the student community working relationship requires ongoing monitoring throughout the placement to ensure priorities and goals remain on track. However, the epistemological challenges of recognising mode 2 knowledge within the academy itself require long-term engagement relationships that can facilitate a more reciprocal relationship between community knowledges and university, discipline-specific knowledges.

\section{ACKNOWLEDGEMENT}

This work is based on the research supported by the University of KwaZulu-Natal Teaching and Learning Fund and National Research Foundation of South Africa (grant number 82616). Any opinion, finding and conclusion or recommendation expressed in this material is that of the author(s) and the university and NRF do not accept any liability in this regard.

\section{REFERENCES}

Alperstein, M. 2007. Getting closer to the community voice in curriculum development: An exploration of the possibilities. Education as Change 11(3):59-67.

Baylor, R. 2011. Practicing adaptive leadership in the college setting. Review of the book 'The practice of adaptive leadership: Tools and tactics for changing your organization and the world [R. A. Heifetz, M. Linsky, \& A. Grashow]. National Clearinghouse for Leadership Programs. Retrieved from https://nclp.umd.edu/.../BookReview-The_Practice_of_ Adaptive_Leadership-Baylor-2011.pdf (accessed 29 January 2015).

Bender, C.J.G. 2008. Curriculum enquiry about community engagement at a research university. South African Journal of Higher Education 22(6):1154-1171.

Bringle, R.G. \& Hatcher, J.A. 1995. A service learning curriculum for faculty. The Michigan Journal of Community Service Learning 2:112-22.

Burke, B.F. 2007. Adaptive leadership as a facilitator of public engagement on environmental sustainability issues. Administrative Theory \& Practice 29(3):412-431.

Caister, K., Green, M. \& Worth, S. 2011. Learning how to be participatory: An emergent research agenda. Action Research 10(1):22-39.

Camacho, M.M. 2004. Power and privilege: Community service learning in Tijuana. Michigan Journal of Community Service Learning Summer:31-42.

Council for Higher Education (CHE). 2006. Service learning in the curriculum: A resource for higher education institutions. Pretoria: CHE.

De Beer, F. \& Swanepoel, H. 1998. Community development and beyond. Pretoria: Van Schaik. 
Department of Education (DoE). 1997. Education White paper 3. A Programme for the Transformation of Higher Education. Pretoria: Government Printers.

Department of Higher Education and Training. 2013. White Paper for Post school Education and Training. Pretoria: DoHET.

Eubank, D., Geffken, D., Orzano, J. \& Ricci, R. 2012. Teaching adaptive leadership to family medicine residents: what? Why? How? Family Systems and Health 30(3):241-252.

Ferreira, R. \& Ebersöhn, L. 2012. Partnering for resilience. Pretoria: Van Schaik.

Foucault, M. 1980. Power/Knowledge. Hemel Hempstead: Harvester Wheatsheaf.

Foucault, M. 1972. The archaeology of knowledge. London: Routledge.

Gibbons, M. 2006. Engagement as a core value in a mode 2 society. Keynote address at CHEHEQC / JET-CHESP Conference on Community Engagement in Higher Education, Cape Town, South Africa.

Grint, K. 2005. Problems, problems, problems: The social construction of leadership. Human Relations 58(11):1467-1494.

Hall, M. 2010. Community engagement in South African higher education. In CHE (Ed.), Kagisano No. 6: Community engagement in South African higher education, 1-52. Auckland Park: Jacana Media (Pty) Ltd.

Hartley, J, \& Bennington, J. 2011. Recent trends in leadership. Paper commissioned by the Kings Fund to inform the leadership commission. Retrieved from http://www.kingsfund.org. $\mathrm{uk} /$ sites/files/kf/recent-trends-in-leadership-thinking-action-in-public-voluntary-servicesectors-jean-hartley-john-benington-kings-fund-may-2011.pdf (accessed 1 September 2014).

Heifetz, R.A. 1994. Leadership without easy answers. London: Harvard University Press.

Heifetz, R.A., Linsky, M. \& Grashow, A. 2009. The practice of adaptive leadership: Tools and tactics for changing your organization and the world. Cambridge, MA: Harvard Business Press.

Hlengwa, A. 2010. Infusing service learning in curricula: A theoretical exploration of infusion possibilities. Journal of Education 48:1-14.

Kania, J. \& Kramer, M. 2011. Collective impact. Stanford Social Innovation Review Winter: 36 41.

Kruss, G. 2012. Reconceptualising engagement: A conceptual framework for analysing university interaction with external social partners. South African Review of Sociology 43(2):5-26.

Laredo, P. 2007. Revisiting the third mission of universities: Toward a renewed categorization of university activities? Higher Education Policy 20:441-456.

Lounsbury, M. \& Pollack S. 2001. Institutionalising civic engagement: shifting logics and the cultural repackaging of service learning in US higher education. Organization 8:319-339.

Mahlomaholo, S. \& Matobako, T. 2006. Service learning in South Africa held terminally captive by legacies of the past. Alternation 13(1):203-217.

Marshall, J.D. 1990. Foucault and educational research. In Ball, S. (Ed.), Foucault and education: Disciplines and knowledge, 11-28. London: Routledge.

Miller, P. \& Rose, N. 1993. Governing economic life. In Gane, M. \& Johnson, T. (Eds.), Foucault's new domains, 75-105. London: Routledge. 
Mitchell, C. \& Rautenbach, S. 2005. Questioning service learning in South Africa: Problematising partnerships in the South African context. A case study from the University of KwaZuluNatal. South African Journal of Higher Education 19(1):101-112.

Moss, J. (Ed.). 1998. The later Foucault. London: Sage.

Nduna, N.J. 2006. Locating and managing service-learning: A complex issue in higher education. South African Journal of Higher Education 20:488-502.

Nduna, N.J. 2007. The community voice on service learning: A good practice guide for higher education. Education as Change 11:69-78.

O'Brien, F. 2012. Constructing service learning in South Africa: Discourses of engagement. In Preece, J., Ntseane, P.G., Modise, O.M. \& Osborne, M. (Eds.), Community engagement in African universities: Perspectives, prospects and challenges, 197-213. Leicester: National Institute of Adult Continuing Education.

Osman, R. \& Attwood, G. 2007. Power and participation in and through service learning. Education as Change 11(3):18-21.

Osman, R. \& Castle, J. 2006. Theorising service learning in higher education in South Africa. Perspectives in Education 24(3):63-70.

Parker, E.A., Myers, N., Higgins, H.C., Oddsson, T., Price, M. \& Gould, T. 2009. More than experiential learning or volunteering: A case study of community service learning within the Australian context. Higher Education Research \& Development 28:585-596.

Petersen, N. \& Henning, E. 2010. Design refinement tools for a teacher education curriculum: The example of a service learning course. Perspectives in Education 28(4):61-71.

Preece, J. 1999. Combating social exclusion in university adult education. Aldershot: Ashgate.

Preece, J. 2013. Service learning and community engagement in South African universities: Towards an 'adaptive engagement' approach. Alternation Special Edition 9:265-291.

Preece, J. 2013a. Community engagement and service learning in a South African university: The challenges of adaptive leadership. South African Journal of Higher Education 27(4):9861004 .

Rule, P. \& John V. 2011). Your guide to case study research. Pretoria: Van Schaik.

Savin-Baden, M. \& Howell Major, C. 2013. Qualitative research: The essential guide to theory and practice. Abingdon: Routledge.

Schmied, V., Mills, A., Kruske, S., Kemp, L., Fowler, C. \& Homer, C. 2010. The nature and impact of collaboration and integrated service delivery for pregnant women, children and families. Journal of Clinical Nursing 19:3516-3526.

Stellenbosch University 2009. Risk management guidelines for community interaction. Stellenbosch: Stellenbosch University. Retrieved from http://admin.sun.ac.za/gi/risk/ Bylae\%20B_Risikobestuursriglyne.pdf (accessed 20 March 2012).

Stephenson Jr, M. 2011. Conceiving land grant university community engagement as adaptive leadership. Higher Education 61:95-108.

Stringer, E. 2004. Action research in education. Columbus, Ohio: Pearson/Merril Prentice Hall.

Swanepoel, H. \& De Beer, F. 2011. Community development: Breaking the cycle of poverty. Lansdowne: Juta and Co. Ltd.

Tomal, D.R. 2005. Action research for educators. Oxford: Rowman and Littlefield. 
UIL. 2013. International Conference on Learning Cities. Nexus UIL Newsletter 8(4):1-6.

Van Schalkwyck, F. \& Erasmus, M. 2011. Community participation in higher education service learning. Acta Academica 43(3):57-82.

Yin, R.K. 2003. Applications of case study research. Second Edition. London: Sage. 